\title{
Dealing with Closed Basins: The Case of the Lower Jordan River Basin ${ }^{1}$
}

\author{
Jean-Philippe Venot, ${ }^{2}$ François Molle ${ }^{3}$ and Rémy Courcier $^{4}$
}

Paper prepared for the World Water Week 2006, Stockholm, August 2006

\begin{abstract}
During the last 50 years, the Lower Jordan river basin experienced a rapid and comprehensive process of development of its rare water resources. This led to its progressive closure: almost no water is left to be mobilized and used while demand, notably in urban areas, keeps increasing. Despite the need to give priority to demand management options to alleviate the Jordanian water crisis, the potential of these options appears limited in the mid-run; the growing demand of the population and the sustaining of agriculture are unlikely to be met without supply augmentation measures which will reopen the basin.
\end{abstract}

\section{Introduction}

The Hashemite Kingdom of Jordan (THKJ) is one of the countries with the scarcest water resources in the world. Due to both physical water scarcity and a high demographic growth during most of the second half of the twentieth century it has been estimated that the per capita endowment of renewable blue water (i.e., surface runoff plus groundwater recharge) is now only 163 cubic meters per year $\left(\mathrm{m}^{3} / \mathrm{yr}\right)$, while the average domestic consumption is 94 liters per capita and per day nationwide (THKJ, 2004). The water resources available in the Jordanian part of the Lower Jordan river basin (LJRB, see figure 2) are currently renewed at a rate of 705 million cubic meters per year $\left(\mathrm{Mm}^{3} / \mathrm{yr}\right)$, including $155 \mathrm{Mm}^{3} / \mathrm{yr}$ of groundwater and $550 \mathrm{Mm}^{3} / \mathrm{yr}$ of surface water. The total water withdrawn within the basin amounts to 585 $\mathrm{Mm}^{3} / \mathrm{yr}$, i.e., $83 \%$ of the renewable surface water and groundwater, but this value obscures the critical overdraft of the main aquifers (Courcier et al., 2005).

The LJRB is a region of prime importance for the country: it includes $83 \%$ of the total population, most of the main industries and $80 \%$ of its irrigated agriculture. It is endowed with $80 \%$ of the country's water resources and uses $75 \%$ of these. During the last 50 years, this basin has experienced a rapid and comprehensive process of mobilization of its rare water resources that has led to its progressive closure: almost no water is left to be mobilized and 
used while demand, notably in urban areas, keeps increasing. Water users and economic sectors are competing for the same rare, yet, quantitatively and qualitatively decreasing water resources.

The main interactions and water allocation problems in the LJRB are schematized in figure 1. Amman (and other cities) are supplied with water coming from the Jordan valley, aquifers, and imports from outer basins. To meet the growing water demand, there is a need to a) improve inflow from the Yarmouk river (dam), b) transfer more water from the valley to Amman (hence reducing agricultural use, although treated wastewater [TTW] is sent back to the valley), c) reduce abstraction from aquifers by highland agriculture in order to preserve water quality, avoid overdraft and reallocate water to cities, and d) rely on (costly) imports from other basins as little as possible.

Figure 1. Schematic representation of main water flows in the LJRB.

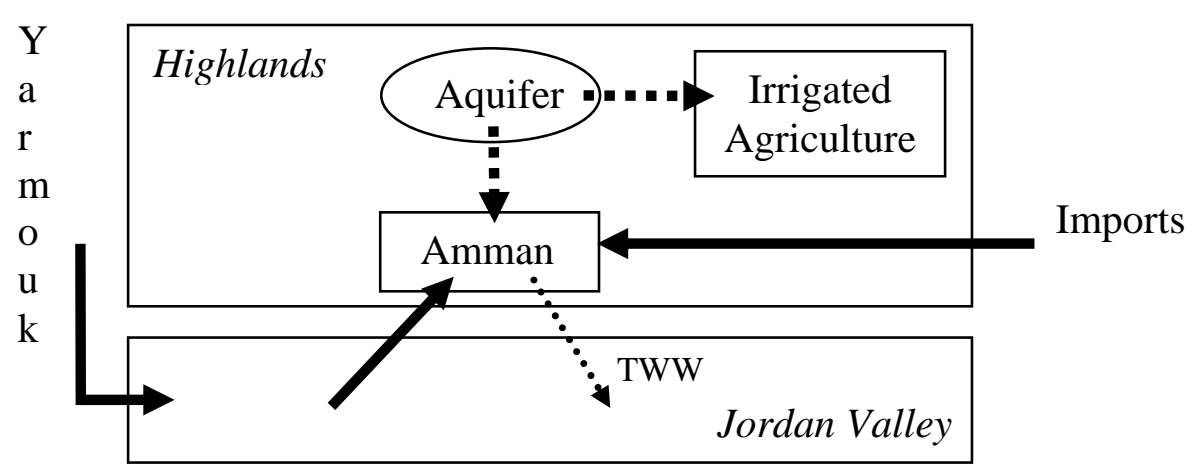

This article describes the closure of a river basin in an arid region. After sketching out the context, it identifies some key driving forces of this closure and quantifies the transformations that occurred. Finally, it highlights the problems faced by the water and agricultural sectors in Jordan, presents options to meet the growing demand of the basin, identifies the problems that future policies may encounter during their implementation, and discusses the scope for reopening the basin.

\section{Main Features of the Lower Jordan River Basin in Jordan}

The Jordan river is an international river which drains a total area of about $18,000 \mathrm{~km}^{2}$ pertaining to five countries: Jordan, Syria, Lebanon, Israel and Palestine (the West Bank). Its three headwater tributaries originate from Lebanon and flow southward into Lake Tiberius (cf. figure 2). With the outflow of the Jordan river from Lake Tiberius virtually blocked by Israel, the lower Jordan river in Jordan on which this study focuses chiefly receives the water from its main tributary, the Yarmouk river (cf. figures 2 and 4). The LJRB represents $40 \%$ of the entire Jordan river basin but only $7.8 \%$ of Jordan's territory. Nonetheless, irrigated agriculture, which uses $70 \%$ of the national water resources, is also mainly concentrated in the basin. From west to east, the LJRB is divided in two main areas: the Jordan valley and the remaining part referred to by the term highlands. 
Figure 2. The LJRB in Jordan.

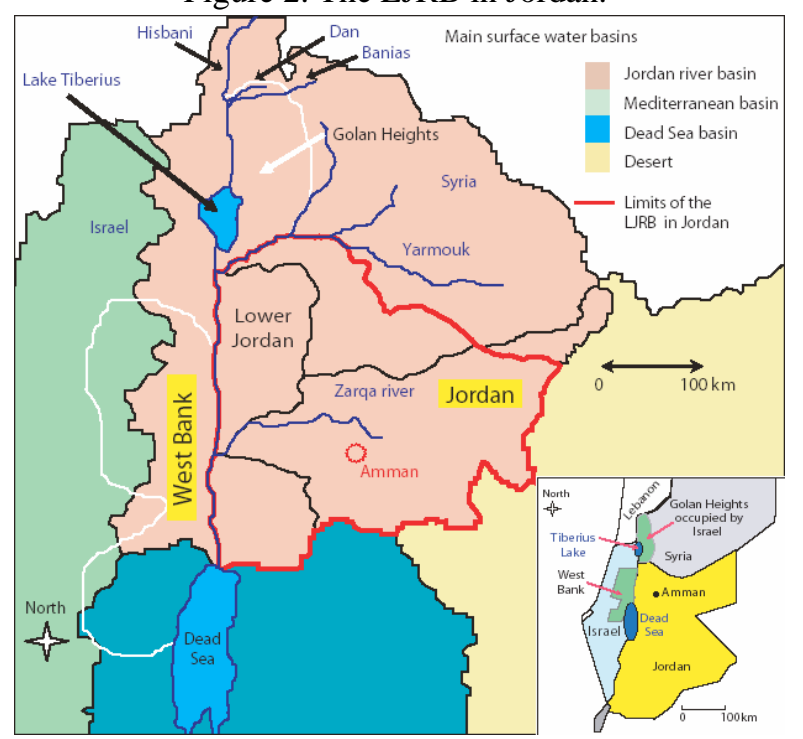

The highlands are composed of a mountain range (uplands) running alongside the Jordan valley and of a desert plateau extending easterly to Syria and Iraq. The mountains are mostly composed of rangelands, with occasional olive trees and stone-fruit trees. The plateau has an average altitude of $600 \mathrm{~m}$ and is mainly used to grow cereals near the mountains, where main urban areas are concentrated and where rainfall is still sufficient for rain-fed agriculture. Eastward, precipitations become scarcer and only nomadic Bedouin livestock farming can be found, with a few localized plots of groundwater-based irrigated agriculture.

The Jordan valley is a 130-km stretch between the Yarmouk river in the north and the Dead Sea in the south. Its altitude varies from $200 \mathrm{~m}$ (in the north) to $400 \mathrm{~m}$ (in the south) below sea level, and its climate is semiarid in the north and arid in the south. Agriculture is possible thanks to pressurized networks fed by a canal and irrigating 20,000 hectares.

\section{Drivers of the Closure of the LJRB}

Prior to water resources development, the original flow of the Jordan river into the Dead Sea varied between 1,100 and 1,400 $\mathrm{Mm}^{3} / \mathrm{yr}$ (Klein, 1998; Al-Weshah, 2000). Half of this volume was coming from the upper Jordan river through Lake Tiberius but is now diverted by Israel to its National Water Carrier. The Yarmouk and the Zarqa rivers are now the two main contributors to surface water resources in the LJRB. Several temporary streams of lesser importance named 'side-wadis' also incise the two mountainous banks and feed the lower Jordan river (cf. figure 4). Groundwater resources originate from four main groundwater basins, namely the Amman-Zarqa, the Yarmouk, the side-wadis and the Jordan valley basins.

A qualitative and quantitative assessment of the history of water resources development and use within the LJRB illustrates the gradual "artificialization" of this river basin from a situation around 1950 where only 10,000 hectares were irrigated, groundwater was untapped, and abundant freshwater flowed to the Dead Sea (cf. figure 4) to the current situation where 46,000 hectares are irrigated, nearly all surface water resources are tapped and committed, groundwater is being severely mined, with only little water reaching the Dead Sea, and a 
saline sink that is the final outlet of the Jordan river (cf. figure 5 ) ${ }^{5}$ Both endogenous and exogenous reasons can explain the increasing pressure on available water resources undergone by the LJRB during the last 50 years (see more details in Courcier et al., 2005).

Figure 3. Water resources development in the LJRB around 1950.
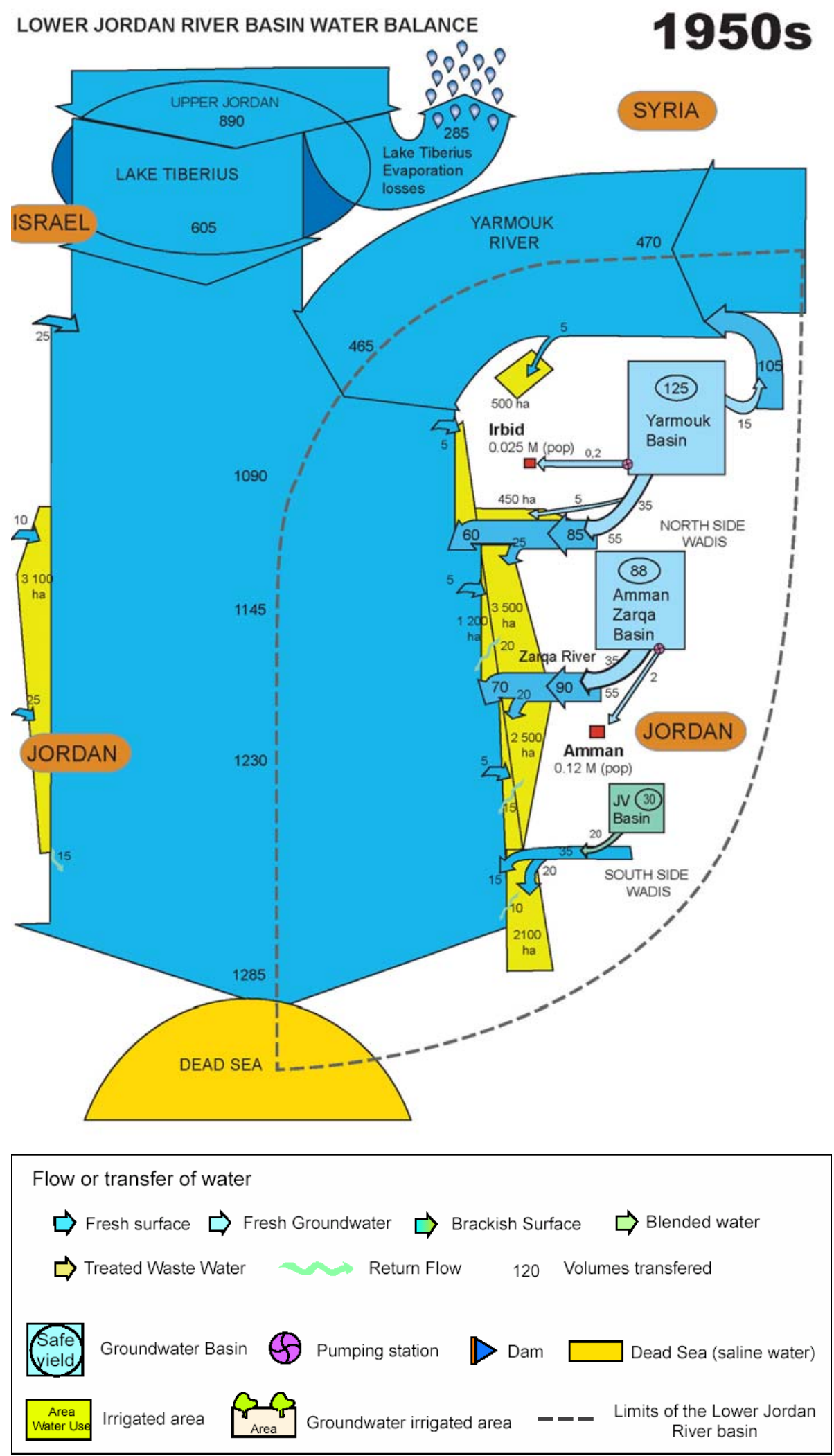

Source: Courcier et al., 2005. 
First, the increasing development of water uses in the upper Jordan (diversion of the river flow by Israel through its National Water Carrier) and the upper Yarmouk by Syria has led to a decrease of the total inflow (rainfall included) into the LJRB from 3,300 to 2,600 $\mathrm{Mm}^{3} / \mathrm{yr}$ between the 1950s and the 2000s.

Second, a high population growth (the Jordanian population has increased more than twelvefold since 1948) linked to both a high natural growth rate (2.4\% per year) and successive waves of migrations, ${ }^{6}$ and the strong development of urban areas such as AmmanZarqa along with improving living standards have led to an increasing water demand.

Despite a high degree of infrastructural development (cf. figure 5), these two trends inexorably led to a sharp decrease of the per capita water availability: estimated at 3,600 $\mathrm{m}^{3}$ in 1946, the renewable blue water per capita and per year decreased to $163 \mathrm{~m}^{3}$ around 2000 and is expected to further decrease down to $90 \mathrm{~m}^{3}$ in 2025.

Water supply in the cities expanded through the development of public wells in and around urban areas and through water transfers for neighboring aquifers (cf. figure 5), with no regard for the unsustainability of these practices in the long term. In the 2000s, municipal and industrial abstraction amounts to $205 \mathrm{Mm}^{3} / \mathrm{yr}$ (i.e., 31\% of current withdrawals), against 10 $\mathrm{Mm}^{3} / \mathrm{yr}$ in the early $1950 \mathrm{~s}$.

Third, irrigated agriculture was promoted, based on social (integrating Palestinian refugee population), political (promoting stability in the Middle East after the creation of Israel) and economic (enhancing Jordan's development) objectives. It is now the main user of the country’s scarce resources.

o Large-scale public irrigation was introduced in the Jordan valley through the construction, between 1958 and 1966, of a main 69-km-long concrete canal (the King Abdullah Canal-KAC) which parallels the river on its eastern bank (cf. figure 5). In 1962, a land reform led to the formation of thousands of small intensive farms and to the settlement of numerous families, including Palestinian refugees, in the valley (Khouri, 1981; Van Aken, 2004). Irrigation facilities were then improved and extended by the government: irrigated agriculture had its heyday in the 1980s and early 1990s when modern irrigation and cropping techniques (greenhouses, drip irrigation, plastic mulch, fertilizer, new varieties, etc.), together with cheap labor from Egypt, became widely available. In the 2000s, about $185 \mathrm{Mm}^{3} / \mathrm{yr}$ were used in the Jordan valley (cf. figure 4).

o In the highlands, several governmental projects aimed at settling Bedouins were implemented in the 1960s: land was irrigated by public deep wells managed by a public authority. Although these projects, focused on subsistence and fodder crops, seem to have failed in most cases, many Bedouins took up the idea during the 1980s and the early 1990s, drilled their own wells and engaged in private irrigation, dramatically depleting groundwater resources. 
Much of the traditional agricultural-cum-livestock model of the nomadic Bedouins was replaced by a modern intensive market-oriented agriculture which expanded both in the Jordan valley and in the highlands. Small-to-medium entrepreneurial farmers supplied growing cities and exported their surplus around the Middle East. This phenomenon described by Elmusa (1994) as the "Super Green Revolution" significantly contributed to the economic development of Jordan during the 1980s but led to a critically unsustainable use of the country's water resources.

Around 2000, total renewable blue water has been evaluated at $705 \mathrm{Mm}^{3} / \mathrm{yr}\left(550 \mathrm{Mm}^{3} / \mathrm{yr}\right.$ of surface runoff and $155 \mathrm{Mm}^{3} / \mathrm{yr}$ of groundwater recharge; THKJ 2004; Courcier et al., 2005). Total water withdrawals in the basin reached $585 \mathrm{Mm}^{3} / \mathrm{yr}$ (i.e., $83 \%$ of the renewable surface water and groundwater), including $275 \mathrm{Mm}^{3} / \mathrm{yr}$ in groundwater abstraction (i.e., a gross overdraft of the aquifers of $120 \mathrm{Mm}^{3} / \mathrm{yr}$ ), and $310 \mathrm{Mm}^{3} / \mathrm{yr}$ of surface water diversion (including $60 \mathrm{Mm}^{3} / \mathrm{yr}$ of treated wastewater). In addition, each year, the basin also imports 30 $\mathrm{Mm}^{3}$ of groundwater and $45 \mathrm{Mm}^{3}$ of surface water from outer basins (cf. figure 5). Uncontrolled flows to the Dead Sea are as low as $315 \mathrm{Mm}^{3} / \mathrm{yr}$ (cf. figure 5).

Agricultural abstraction accounts for $79 \%$ of the total withdrawals in the LJRB ( $455 \mathrm{Mm}^{3} / \mathrm{yr}$ ) and irrigated agriculture competes with the municipal and industrial sectors as it jeopardizes future low-cost uses of the Jordanian aquifers for domestic purposes. Irrigated agriculture is indeed one of the main activities responsible for the current dramatic over-depletion of the basin's aquifers: according to the records of the Ministry of Water and Irrigation, agricultural groundwater abstraction in the LJRB reached $121 \mathrm{Mm}^{3} / \mathrm{yr}$ in 2004.

The LJRB is a closed basin where there are no uncommitted outflows except when the Yarmouk river is in spate and flows exceed diversion capacity. Both the Jordan valley and the highlands, on the one hand, and agriculture and cities, on the other, are interconnected and interdependent. Spatial interconnectedness of uses and flows can be sensed from figure 5.

This interdependence means that, under a scenario with no interbasin transfers, urban water needs will have to be covered through more transfer from agriculture and that competition for groundwater can only be alleviated, if not remedied, by a decrease of irrigated areas in the highlands. It also means that there is no slack in the system and that the brunt of hydrologic fluctuations and supply uncertainty will have to be borne by agriculture. 
Figure 4. Water resources and uses in the LJRB around 2000.

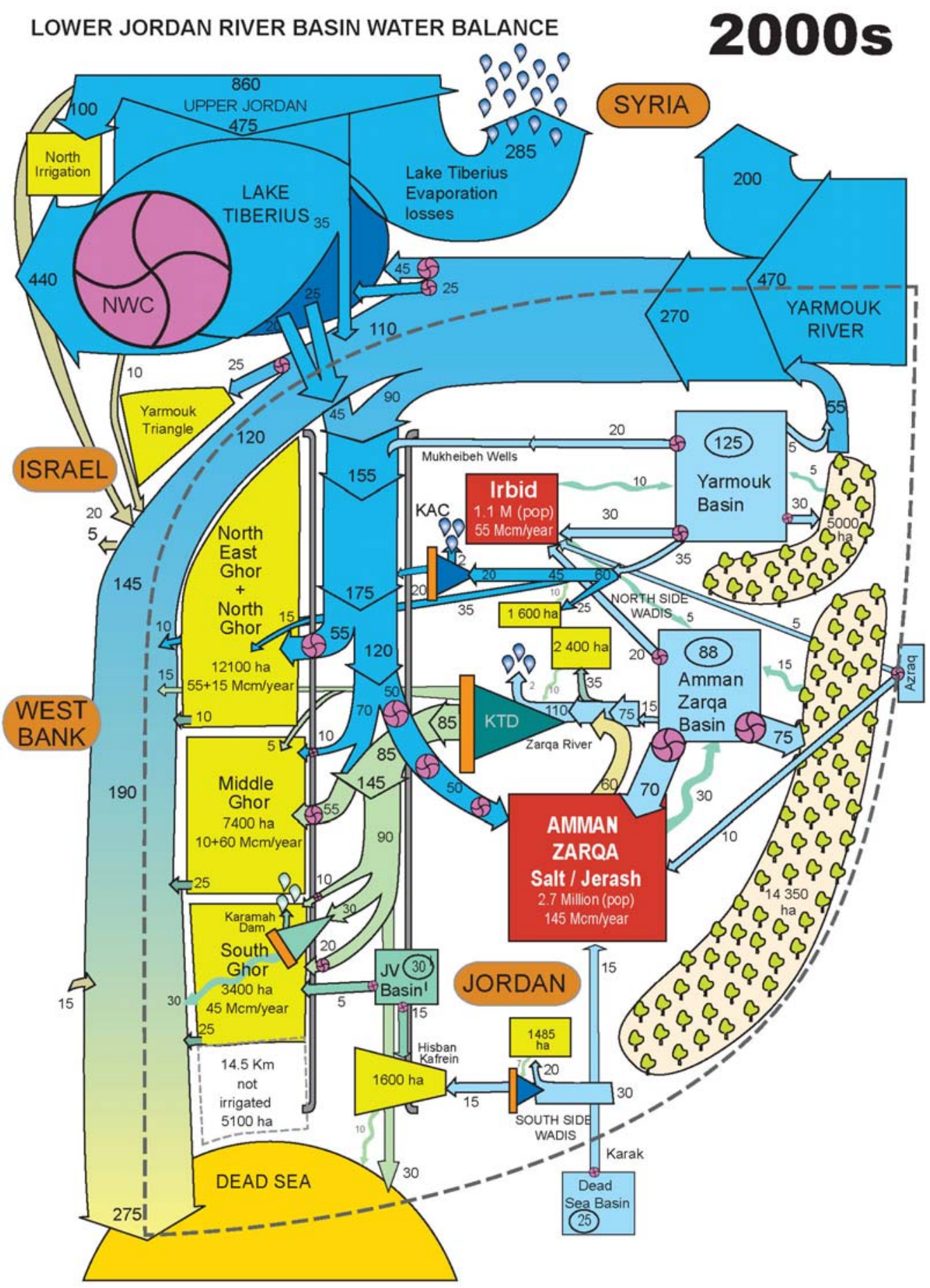

Source: Courcier et al., 2005. 


\section{Changing components of the water accounting}

This qualitative description of the transformation of the LJRB can be paralleled by a quantitative accounting of the (im)balance between supply and demand. This water accounting draws on the categories of water balance proposed by Molden (1997). We first give a detailed accounting of the water flows in 2000 (current situation) and then describe the historical changes in the components of the water balance.

We considered here that there is no commitment of the water entering the Dead Sea, which is, therefore considered as a sink. Accounting for the environmental flow needed to maintain the level of the Dead Sea as a "commitment" would actually distort our water balances to the point of rendering it meaningless. This would point to an extreme overcommitment since the basin has been having a deficit of around $540 \mathrm{Mm}^{3} / \mathrm{yr}$ since the early 1950s (figure 5). Based on the definition of water depletion as the use or removal of water from a water basin that renders it unavailable for further uses (Molden, 1997), the LJRB consumed 86\% of its net inflow (i.e., rainfall, interbasin transfers, and lateral groundwater flows) through evaporation and evapotranspiration in 2000. The only flows reaching the Dead sea are coming (uncontrolled) from the upper Yarmouk basin $\left(110 \mathrm{Mm}^{3}\right)$, the upper Jordan $\left(10 \mathrm{Mm}^{3}\right)$, return flows from irrigated areas $\left(70 \mathrm{Mm}^{3}\right)$ and excess or uncontrolled flows from canals and sidewadis $\left(125 \mathrm{Mm}^{3}\right.$ ) (cf. figure 5). Further, beneficial depletion (irrigation, rain-fed agriculture, industrial and drinking uses) accounts for 33\% of the net inflow, low beneficial depletion (natural vegetation) for $15 \%$ and non-beneficial depletion (through bare land evaporation) for $38 \%$ of it. The remaining $14 \%$ flows into the Dead Sea.

Most of the depletion takes place in desert areas (44\% of the total water depleted in the LJRB). Evaporation in irrigated fields accounts for $18 \%$ of the total depletion, as much as the depleted volumes through either rain-fed agriculture or natural vegetation, despite their much smaller areas (cf. table 1). Finally, despite all the allocation conflicts between cities and agriculture, the share of municipal and industrial uses is negligible, representing only $3 \%$ of the total depleted fraction in the LJRB (not shown).

From a situation in the 1950s when few of the surface water and groundwater resources were put into use, to the current situation of overexploitation, the terms of the water balance have varied sharply. Table 1 summarizes main indicators of water mobilization and uses in the LJRB and their evolution during the 1950-2000 period with some projections for 2025.

The first notable evolution is that of land use. Irrigated areas increased more than fourfold between 1950 and 2000. This total area (including both schemes in the valley and groundwater-based agriculture in the highlands) is projected to decrease by $10 \%$ in the next quarter century. Rain-fed cropping areas have significantly increased in the 1950-1975 period, when cereals provided work and food to a growing population. This extensive type of agriculture later declined, with the growing influence of urban areas and a shift towards nonagricultural activities. The natural vegetation contracted and expanded in opposition with these changes. 
Table 1. Indicators of mobilization and water uses $\left(\mathrm{Mm}^{3} / \mathrm{yr}\right)$ in the LJRB and their evolution during the period 1950-2025 (adapted from Courcier et al., 2005).

\begin{tabular}{|c|c|c|c|c|}
\hline & 1950 & 1975 & 2000 & 2025 \\
\hline Net inflow & 3,278 & 2,635 & 2,605 & 2,598 \\
\hline Renewable blue water & 1,588 & 823 & 705 & 861 \\
\hline Controlled renewable blue water & 493 & 543 & 545 & 806 \\
\hline Groundwater abstraction & 6 & 110 & 275 & 255 \\
\hline Total withdrawals (with imports) & 101 & 316 & 660 & 967 \\
\hline Total outflow to the Dead Sea & 1,295 & 505 & 315 & 200 \\
\hline $\begin{array}{l}\text { Total withdrawals } \\
\text { (\% of renewable blue water) }\end{array}$ & 6 & 38 & 94 & 112 \\
\hline $\begin{array}{l}\text { Total withdrawals } \\
\text { (\% of controlled renewable blue water) }\end{array}$ & 20 & 58 & 121 & 120 \\
\hline Volume of withdrawals depleted & 54 & 202 & 474 & 705 \\
\hline $\begin{array}{l}\text { Volume of withdrawals depleted } \\
\text { (\% of renewable blue water) }\end{array}$ & 3 & 24 & 67 & 82 \\
\hline $\begin{array}{l}\text { Volume of withdrawals depleted } \\
\text { (\% of controlled renewable blue water) }\end{array}$ & 11 & 37 & 87 & 87 \\
\hline Depletion-irrigation (\% of total depletion) & 4 & 11 & 18 & 15 \\
\hline Depletion-rain-fed agriculture (\% of total depletion) & 17 & 26 & 18 & 18 \\
\hline Depletion-natural vegetation (\% of total depletion) & 26 & 18 & 17 & 19 \\
\hline Beneficial depletion & 391 & 756 & 867 & 945 \\
\hline Total depletion & 1,893 & 2,054 & 2,235 & 2,398 \\
\hline Natural vegetation (ha) & 145,400 & 118,850 & 114,200 & 122,900 \\
\hline Rain-fed crops area (ha) & 271,200 & 334,900 & 260,600 & 269,300 \\
\hline Irrigated area (ha) & 10,250 & 24,900 & 45,800 & 37,400 \\
\hline
\end{tabular}

With only $315 \mathrm{Mm}^{3}$ reaching the Dead Sea every year, the deficit in inflow resulted in a gradual and constant drop in the water level of the inland sea. Deducting rainfall directly evaporated from crop and bare soils, the renewable blue water shows a drop by $56 \%$ with a slump at $705 \mathrm{Mm}^{3}$ in 2000 and a subsequent increase by 23\% projected for 2025, because of water imports. The controllable renewable blue water is significantly lower $\left(545 \mathrm{Mm}^{3}\right)$ since uncontrolled and brackish flows from the Yarmouk, side-wadis or Israel are discounted. The expected increase in 2025 mirrors the imports and the larger share of the Yarmouk flow stored in the Wehdah dam (cf. below). Strikingly, withdrawals now amount to $121 \%$ of the controlled renewable blue water (i.e., $660 \mathrm{Mm}^{3} / \mathrm{yr}$ ) because of groundwater overabstraction and multiple diversions (return flows from wadi-irrigation or from Amman are reused downstream in the south of the Jordan valley).

Aquifers began to be overexploited during the last quarter century and the net overdraft is now reaching $32 \mathrm{Mm}^{3} / \mathrm{yr}$. Figure 6 gives the evolution of the depleted fraction distributed over three categories (process/beneficial, low-beneficial, and non-beneficial). 
The biggest changes occurred in the 1950-1975 period when total beneficial depletion increased dramatically from 391 to $756 \mathrm{Mm}^{3} / \mathrm{yr}$ (or from 21 to $37 \%$ of the total depleted fraction) and the total depletion from 58 to $78 \%$ of the net inflow. This happened because cultivated areas increased and the net inflow was curtailed by the diversion of the upper Jordan river by Israel. This trend continued in the last quarter century and took the beneficial depleted fraction to $39 \%$ of total depletion in the basin in the $2000 \mathrm{~s}\left(867 \mathrm{Mm}^{3} / \mathrm{yr}\right.$; partly due to the overexploitation of the aquifers). At the same time, the total depleted fraction increased to $86 \%$ of the net inflow and will continue to increase up to $92 \%$ in the next 25 years; only $8 \%$ of the inflow will reach the Dead Sea (not considering volumes possibly transferred to the Dead Sea by the Red-Dead canal; cf. below).

Figure 5. Evolution of depleted fractions in the LJRB (nominal values and percentage).

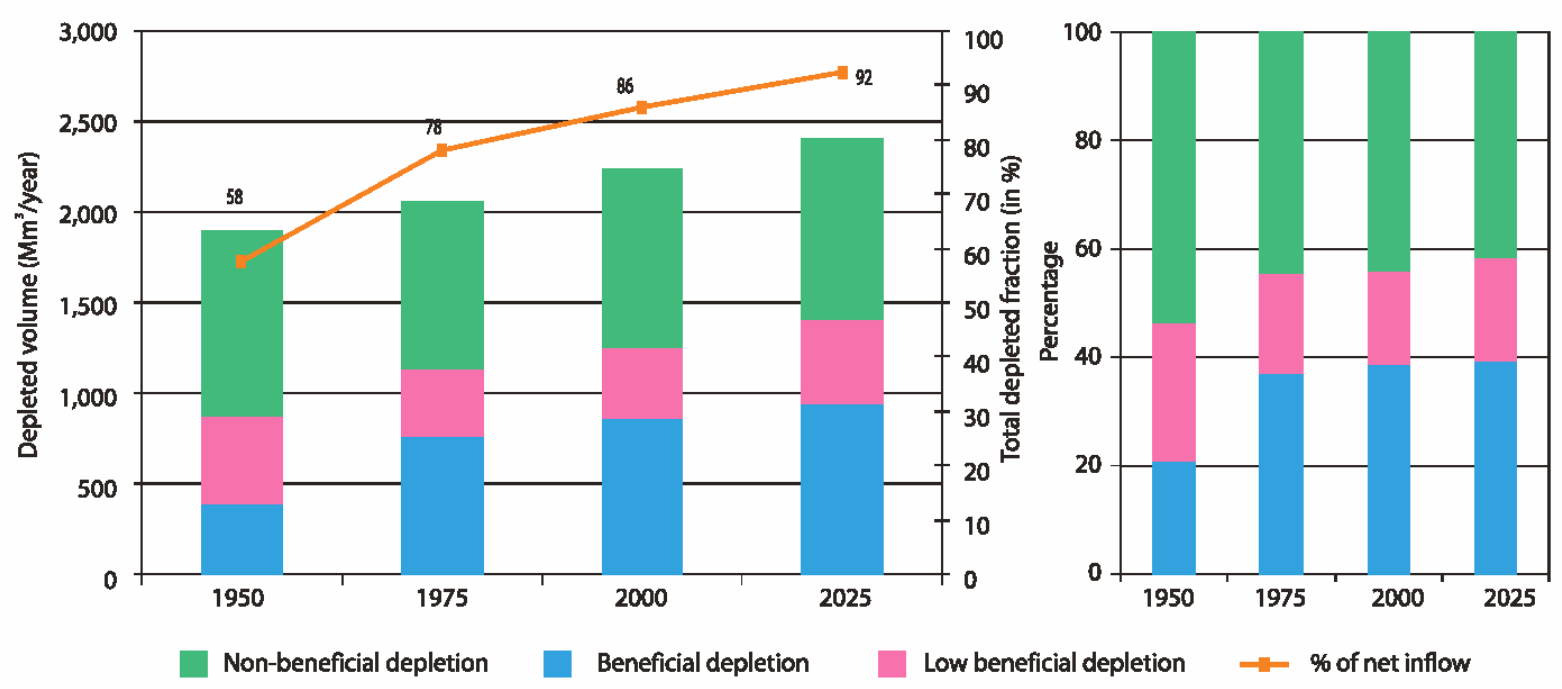

Source: Courcier et al., 2005.

Non-beneficial and low-beneficial depleted fractions stayed (and will remain) roughly constant since 1950, while their relative share continuously decreased because of the expansion of the cropped area (both rain-fed and irrigated) contributing to raising the beneficial depleted fraction. Further, irrigation depletion dramatically increased from $2 \%$ of the net inflow in 1950 to around 18\% at present (making up 45\% of the beneficial depleted fraction). Again, these values are expected to decline, under the assumption that highland irrigated agriculture is to be reduced and that more water is to be imported to cities. Finally, overall efficiency of water use in the basin, considered as a system and expressed both in percentage of renewable blue water or in percentage of controlled renewable water, has sharply increased and reaches 67 and 87\%, respectively (cf. table 1). These values are expected to reach 82 and $87 \%$ in 2025.

This underlines the fact that the LJRB is a closed basin where almost no water is left to be mobilized and used. In other words, there are very limited prospects to alleviate the Jordanian water crisis by technical improvement aiming at increasing water use efficiency (the ratio of depleted water to water withdrawals reaches $72 \%$ ). 


\section{Reopening the LJRB: Demand management vs. supply augmentation options?}

The exploitation of water resources increased sharply between 1975 and 1995 but little change was apparent in the way water resources were managed even if, in the beginning of the 1990s, awareness of a "water crisis" was developing among the users. Until the mid1990s, water was largely considered as a "sleeping resource" to be found and mobilized by ever-effective and efficient new techniques. The mid-1990s marked a turning point: a more comprehensive hydrological knowledge and the 1994 Peace treaty that fixed the repartition of water resources between Israel and Jordan put the water crisis faced by these countries in sharp relief.

The Jordanian government is engaged in a critical reorientation of its water policy. The publication of Jordan's water strategy and policies in 1997 (THKJ \& MWI, 1997), the creation in 1992 of the Ministry of Water and Irrigation responsible for the management of the entire water sector, the publication of several World Bank reports (World Bank, 2001a, 2001b), the official issuance of a national water master plan (THKJ, 2004), all called for implementing effective demand management options (notably through a reduction of the agricultural water consumption and a better management of urban water supplies) that would displace traditional supply augmentation options (Al-Jayyousi, 2000). This orientation was forcefully endorsed by bilateral cooperation partners such as GTZ (Magiera et al., 2006), USAID and CIDA/IDRC (http://www.idrc.ca/waterdemand/). Actions taken to manage the actual demand included:

- Freezing of well-drilling authorizations in 1992.

- Implementation of a tax of US\$0.35/ $\mathrm{m}^{3}$ for any water pumped and sold/used for industrial or aesthetic purposes (since 1994) as well as domestic purposes (since 2002).

- Metering of agricultural groundwater abstraction and the controversial establishment of a tax on the volumes pumped over a given threshold to preserve the quality of the main Jordanian aquifers (THKJ, 2002, 2004a; Chebaane et al., 2004; Venot \& Molle, 2006).

- A reduction — reflecting water availability — of the quotas allocated to farmers and government payments to farmers for fallowing their land in the valley during droughts.

- Modernization of irrigation systems and different measures to improve irrigation efficiency.

- Recommendation to increase irrigation water charges in the valley (THKJ \& MWI, 1997, 1998, 2004b; World Bank 2003; USAID 2006).

- Recycling of water through an increasing use of treated wastewater in the south of the Jordan valley (McCornick et al., 2001, 2002; THKJ et al., 2002; Scott et al., 2003).

- Rehabilitation of the Greater-Amman supply network to improve distribution and reduce unaccounted for water (Decker, 2004). 
- Transfer of the management of urban water supply to the Amman city to a private company (Suleiman, 2002; Darmane, 2004).

- Increasing reallocation of water from agriculture to urban uses (around 2000s, 50 $\mathrm{Mm}^{3} / \mathrm{yr}$ are pumped in the Jordan valley and transferred to Amman; this quantity is expected to increase to $90 \mathrm{Mm}^{3} / \mathrm{yr}$ at the 2025 horizon; Courcier et al., 2005).

- Promotion of efficient use of water resources through agriculture focused on removal of subsidies, lifting of price controls, liberalization of the external trade regime, and deregulation of the land market in the Jordan valley which were part of the ASAL (agriculture sector structural adjustment loan) World Bank loan (Pitman, 2004).

Whether significant regional water savings can be achieved through demand management options is doubtful: Venot \& Molle (2006) have shown that despite the hope vested in water pricing strategies, little reduction of agricultural water use would be achieved through such measures (on the other hand, recovering O\&M costs is achievable in the Jordan valley). Pricing policies were both expected to take groundwater abstraction rates close to the annual recharge by the year 2005 (Pitman, 2004), and to reduce agricultural diversion in the Jordan valley (World Bank, 2003). However, in line with Berkoff (1994) who recognized 'that it is inconceivable that [charges] would be high enough to balance supply and demand,' a World Bank (2003) report indeed acknowledged indeed that 'it was anticipated that increased water tariffs would reduce agricultural water use. This did not happen.'

The water and agriculture sectors face a complex set of social, technical and economical problems. Irrigated agriculture competes with domestic water use not so much in terms of present allocation (water is already reallocated from agriculture in the Jordan valley to the M\&I sector in Amman; cf. figure 5) but, rather, in terms of future use, since the current groundwater overdraft in the highlands reduces water availability for future urban uses. In addition, the aquifer gets increasingly saline with depth and this salinity is compounded by the use of fertilizers and pesticides; this implies that more costly alternative sources will have to be tapped in the near future.

Irrigated agriculture in the highlands includes intensive olive trees, fruit-tree plantations and open-field vegetable cultivation. It is unlikely that irrigation efficiency can be significantly improved because olive trees are already under-irrigated, efficiency in fruit-tree orchards is already high and vegetables have low returns: improving efficiency would require investment in technology and qualified labor that are a) higher than gains resulting from a reduced water bill and b) beyond the capacity of most of these farmers, many of whom are indebted. A substantial drop in water abstraction can only be obtained through the diminution of either the cultivated area or the number of wells in use. This can be achieved by negative incentives (higher tariffs, petrol taxation, stricter enforcement of abstraction limits) but recent political crises suggest that these are unlikely to be accepted without attendant positive incentives, such as buying-out of wells (a measure envisaged by the government and considered positively by $50 \%$ of farmers; Chebaane et al., 2004), compensation for the uprooting of olive trees in the eastern desert (Fitch, 2001), and substituting treated wastewater for groundwater (Shaner, 2001). 
In the valley, improved efficiency will come from better canal management (after the Wehdah dam allows storage and fine-tuning of releases), possible improvements in collective pressurized networks and upgrading of individual plot-level equipment: however, the scope for saving water is limited to certain periods (when requirements are lower than supply or quotas) and by uncertainty about the soil salinity problems which may arise if salt lixiviation is reduced (McCornick et al., 2001). Existing differential quotas between banana, citrus and vegetable growers may also result in economic efficiencies if they protect extensive and lowvalue crops and hinder intensification. It is already clear that freshwater will be increasingly transferred to Amman and that the valley will have to use a growing share of treated wastewater.

Irrigated agriculture is now the residual user of water and is increasingly vulnerable to drought. It does not enjoy anymore the very favorable conditions of the 1970s and the 1980s and is affected by changes in relative competitiveness with regard to other regional producers and by changes in market prices. Due to its limited importance for the national economy (5\% of the labor force; 3 to $4 \%$ of the GDP) its future is uncertain. Preserving a local production of fruits and vegetables to supply the large local market, stabilizing the trade balance (12\% of Jordanian exports are fruits and vegetables) and insuring a certain level of revenue to farmers remain important objectives. However, policies may be needed to phase out segments of the agriculture sector which consumes water-scarce resources while yielding relatively low benefits: olive trees in desert areas of the highlands (which total half of the highland irrigated area and deplete one-fourth of the total groundwater abstracted for agricultural purposes), citrus orchards in the valley and, to a lesser extent, bananas also in the valley, whose return is partly due to protective customs duties (see Venot \& Molle, 2006 for more details).

Such evolutions are constrained by two separate factors: The first one is political and relates to the political clout of some Bedouin tribes and landowners both in the highlands and the valley who have resisted water pricing policies that would have constrained their use of water or their income (Pitman, 2004). The second factor is the social necessity of balancing family farming and agro-business, social stability and economic efficiency. As a rule, state policies include investments/subsidies to allow modernization of family farms in order to better compete with highly capitalized operators. Even in Europe this necessity is crucial and recent simulation of the response of European agriculture to the European Water Directive Framework showed a need for a distinction between "socially driven irrigation" and "commercial systems" (Berbel et al., 2005).

Despite political priority and emphasis placed on demand management policies, supply augmentation projects have been pursued, including interbasin transfers of desalinized water from the Maïn springs and Mujib wadi, south of the LJRB and the ongoing construction of the Wehdah dam. The mid- and long-term solutions presently envisioned are eventually typical capital- and technology-intensive supply augmentation projects, including the transfer to Amman of the water of the Disi aquifer used by both Jordan and Saudi Arabia mainly for irrigation. But the epitome of these planned technical solutions is the project of transferring $1,500 \mathrm{Mm}^{3} / \mathrm{yr}$ of seawater from the Red Sea to the Dead Sea, desalinating part of it to meet 
urban water needs (this project would, in the long run, increase, by one half, the total available freshwater in Jordan) and countering the historical decline of the Dead Sea level (cf. figure 7).

Figure 6. Projected situation of water use patterns in the LJRB by the mid-2020s.

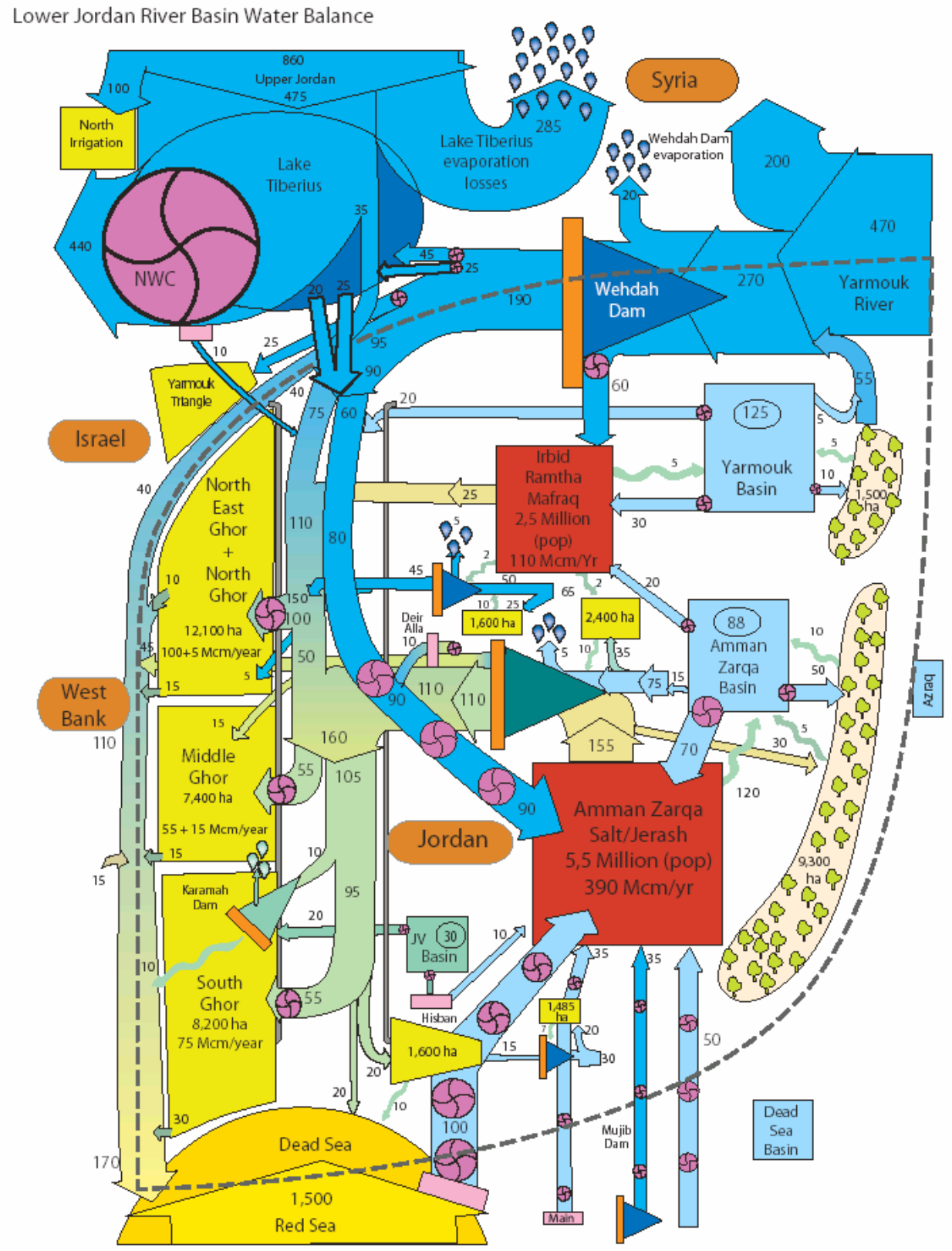

Source: Courcier et al., 2005.

This may be seen as the lasting dominance of the engineering-based approach but this also shows that however desirable they may be, demand-management options may only alleviate the actual situation without providing long-term solutions. This does not mean that finetuning of irrigation supply in the valley or further adoption of water saving technology does not need to be considered, but it does set a drastic limit to what can be achieved through conservation means. Just as in other water-stressed environments (as in the case of California 
described by Turral 1998), basin closure means that overall basin efficiency is close to maximum and that all options (conservation, recycling, reallocation, interbasin transfers) must generally be pursued together. In the present case, this suggests that transfers may well be needed in the future, although this conclusion should not be taken as a justification for disregarding short-term demand management options.

\section{Conclusion}

This article illustrates the gradual "anthropogenization" of a river basin over a time span of 50 years. The process of closure has been very rapid and mainly driven by three processes which put ever-increasing pressure on the rare available water resources of the basin: increasing water diversions in the upstream basin, a high population growth and a rapid development of both irrigated agriculture and cities. At present, the LJRB is a closed basin, water resources are overcommitted, and no resources are left to be mobilized and used. Because of the reuse of water and of the current groundwater overdraft, withdrawals amount to $121 \%$ of controllable blue water. Considering the sustaining of the Dead Sea level as an objective, rather than taking the Dead Sea as a sink, would point to even more dramatic overuse.

Such basin closure means that all uses are increasingly interdependent, through a complex web of natural flows, diversions and return flows. This tight interdependence and the limited basin outflow also mean that growing urban needs will have to be covered through reallocation of water away from agriculture or from interbasin transfers. With little slack in the system, hydrologic vagaries will primarily affect agriculture and contingency plans must be prepared in advance in order to avoid crises.

Finally, the relatively high water use efficiency, the limited losses through percolation and the costs of adopting high-tech equipment signal that the scope for water savings both at the local and basin scales is more limited than often believed. A ceiling has been reached: demandmanagement options must be pursued aggressively and may alleviate the actual situation but they may not bring long-term solutions that will eventually be provided by supply augmentation projects (interbasin transfers, desalinization). Although such projects implicitly negate the policy emphasis put on demand management and may be taken as a sign of the enduring priority given to capital-intensive projects, they may also signal that reopening river basins through water transfers and desalinization, as also observed in Israel, might become a common characteristic of the evolution of river basins in arid countries.

\section{Notes}

\footnotetext{
${ }^{1}$ Most of the conclusions presented in this paper are derived from Courcier et al. (2005) and Venot \& Molle (2006). This research was supported by a grant from the Government of the Netherlands to the Comprehensive Assessment and by the Ministry of Foreign Affairs, France.

${ }^{2} \mathrm{PhD}$ Scholar at the International Water Management Institute (IWMI), Hyderabad, India and at the Laboratoire Gecko, University of Paris X-Nanterre. j.venot@cgiar.org

${ }^{3}$ Senior researcher at the Institut de Recherche pour le Développement, 911 Avenue Agropolis, 34000 Montpellier, France; joint appointment with the International Water management Institute. f.molle@cgiar.org
} 
${ }^{4}$ Formerly head of the MREA (French Regional Mission for Water and Agriculture) of the French Embassy in Amman, Jordan.

${ }^{5}$ This view considers the Dead Sea as a sink; current flows are so much under "natural" flows that there is no way environmental sustainability of the Dead Sea can be factored in as a policy objective under current circumstances (unless seawater is transferred from the Red Sea).

${ }^{6}$ Jordan underwent successive waves of migrants due to the wider political situation in the Middle East: 350,000 Palestinian refugees after the 1948-1949 Israeli-Arab war; 405,000 persons after the 6-day war of 1967; 635,000 persons between 1988 and 1992 (after the abandonment of any administrative relations with the west bank in 1988 and the Gulf crisis of 1990/91). It is estimated that further 500,000 persons (mainly Iraqis) have fled the Gulf for Jordan after the second gulf war of 2003. The population of Jordan was estimated at 5.35 millions in 2004 (Pre-1948 population was about 430,000 persons).

\section{Bibliography}

Al-Jayyousi, O. (2000) Paradigm shift in agriculture in the Jordan Valley: Implication for food security. Duplicated.

Al-Weshah, R. A. (2000) Optimal use of irrigation water in the Jordan valley: A case study. Water Resources Management, 14, 327-338.

Berbel, J., Gutiérrez, C. \& Viaggi, D. (2005) Summary and conclusions. In WADI - The Sustainability of European Irrigated Agriculture under Water Framework Directive and Agenda 2000, (ed.) J. Berbel and C. Gutiérrez. (Seville, European Commission, Joint Research Center, Institute of Prospective Technological Studies), pp. 173-200.

Berkoff, J. (1994) Issues in water pricing. Working Paper. Jordan Agricultural Sector Adjustment Loan. Duplicated.

Chebaane, M., El-Naser, H., Fitch, J., Hijazi, A. \& Jabbarin, A. (2004) Participatory groundwater management in Jordan: Development and analysis of options. Groundwater: from development to management. Hydrogeology Journal, 12, 1, 14-32.

Courcier, R., Venot, J. P. \& Molle, F. (2005) Historical Transformations of the Lower Jordan River Basin (in Jordan): Changes in Water Use and Projections (1950-2025). Comprehensive Assessment Research Report 9. (Colombo, Sri Lanka, Comprehensive Assessment Secretariat).

Darmane, K. (2004) Gestion de la Rareté: Le Service d'eau Potable d'Amman Entre la Gestion Publique et Privée. IWMI-IFPO-MREA Working Paper. (Amman, French Regional Mission for Water and Agriculture).

Decker, C. (2004) Managing water losses in Amman's renovated network: A case study. Paper presented at the Water Demand Management Forum. Dead Sea, Jordan. 31 May-03 June 2004.

Elmusa, S. S. (1994) A Harvest of Technology, The Super Green Revolution in the Jordan Valley. (Georgetown, Center for Contemporary Arab Studies, Georgetown University).

Fitch, J. B. (2001) Curtailment of Groundwater Use for Irrigated Agriculture in the Amman-Zarqa Basin. Uplands: An Economic Analysis. For ARD-USAID, 38p + Appendixes. Amman: USAID. 
Khouri, R. G. (1981) The Jordan Valley: Life and Society below Sea Level. London and (New York, Longman).

Klein, M. (1998) Water balance of the upper Jordan river basin. Water International, 23, (4), 244-248.

Magiera, P., Taha, S. \& Nolte, L. (2006). Water demand management in the Middle East and North Africa. Management of Environmental Quality, 17, 3, 289-298.

McCornick, P., Haddadin, M. \& Sabella (2001) Water Reuse Options in the Jordan Valley. Water Reuse Component, Water Policy Support Activity. (Amman, Jordan, USAID).

McCornick, P. G., Taha, S. S. E. \& El-Nasser, H. (2002) Planning for Reclaimed Water in the Amman-Zarqa Basin and Jordan Valley. Environmental and Water Resources Institute, Conference and Symposium on Droughts and Floods. (Roanoke, Virginia, USA. American Society of Civil Engineering).

Molden, D. (1997) Accounting for Water Use and Productivity. SWIM Paper 1. (Colombo, Sri Lanka, International Irrigation Management Institute).

Pitman, G. T. K. (2004) Jordan: An Evaluation of Bank Assistance for Water Development and Management. A Country Assistance Evaluation. (Washington, D.C., World Bank).

Scott, C. A., El-Naser, H., Hagan, Ross E. \& Hijazi, A. (2003) Facing water scarcity in Jordan: reuse, demand reduction, energy and transboundary approaches to assure future water supplies. Water International, 28, 2, 209-216.

Shaner, W.W. (2001). Economics Study for Managing Water Reuse in the Amman-Zarqa Basin and the Jordan Valley. Study for ARD-USAID.

Suleiman, R. (2002) Privatisation of Jordan's Capital Water Utility: Assessment and Evaluation of Water Supply and Wastewater Services of Amman Governorate. TRITALWR Master Thesis. Stockholm.

THKJ (The Hashemite Kingdom of Jordan) (2004) National Water Master Plan. (Amman, Jordan, German Agency for Technical Cooperation).

THKJ \& MWI (Ministry of Water and Irrigation) (1997) Jordan's Water Strategy and Policies. (Amman, Jordan, THKJ \& MWI). 7p.

THKJ \& MWI (1998) Irrigation Water Policy. (Amman, THKJ \& MWI). 8p.

THKJ \& MWI (2002) Underground Water Control Bylaw. Bylaw No. 85 of 2002. (Amman, Jordan, THKJ \& MWI).

THKJ \& MWI (2004a) Amendment to the Underground Water Control Bylaw. Bylaw No. 85 of 2002. (Jordan, THKJ \& MWI).

THKJ \& MWI (2004b) Tariff Systems in the Water Sector. (Amman, THKJ \& MWI).

THKJ \& MWI (2002) 2003-2008 Strategic Plan. (Amman: Ministry of Water and Irrigation).

Turral, H. (1998) Hydro-logic? Reform in Water Resources Management in Developed Countries with Major Agricultural Water Use - Lessons for Developing Nations. (London, Overseas Development Institute), 174 p. 
USAID (2006) Jordan Water Strategy. WATERIQC. Integrated water and coastal resources management. http://www.wateriqc.com/

Van Aken, M. (2004) Social and Cultural Aspects of Current and Future Governance for the Management of Water Resources in the Jordan River Valley. (Amman, Jordan, French Regional Mission for Water and Agriculture).

Venot, J-P. \& Molle, F. (2006) Irrigated Agriculture, Water Pricing and Water Savings in the Lower Jordan River Basin (in Jordan). Research Report. (Colombo, Sri Lanka, International Water Management Institute). Forthcoming.

World Bank (2001a) Jordan - A pioneer in water sector reform. Hashemite Kingdom of Jordan Update Fourth Quarter 2001, pp. 11-15. (Washington, D.C., World Bank).

World Bank (2001b) The Hashemite Kingdom of Jordan: Water Sector Review Update. Main Report. (Washington, D.C., World Bank).

World Bank (2003) Performance Assessment Report: Jordan. Agricultural Sector Adjustment (Loan No. 3817-JO) and Agricultural Sector Technical Support Project (credit No. 3818-JO). (Washington, D.C., World Bank). 